\title{
Bilingual Children's Language and Literacy Development
}

Roger Barnard and Ted Glynn, Eds. Clevedon, England: Multilingual Matters. 2003. Pp. $\mathrm{xi}+287$.

If asked to name a place that typifies issues in multicultural and multilingual pedagogy, few educators worldwide would think first of New Zealand. Yet in a world of increasing globalization, where many of us are forced to put English first while striving to preserve and respect the cultural and linguistic distinctiveness of our own or our students' ethnicities, New Zealand presents an instructive case study. Long submerged under the dominant Englishspeaking Pakeha (euro-New Zealand) culture, the indigenous language of the Maori people foundered until a recent movement for cultural recognition brought it into the foreground of national consciousness. During roughly the same period, since a 1987 change in the immigration law, New Zealand has experienced dramatic changes in its cultural and linguistic landscape. Most notably, a significant influx of Pacific islanders and Asians of various nationalities has led to the presence of a range of new cultural communities and to a major challenge for New Zealand's schools.

This volume edited by Roger Barnard and Ted Glynn-Bilingual Children's Language and Literacy Development - has a subtitle that, curiously enough, appears only on the copyright page: New Zealand Case Studies. Yet this is not the only initially puzzling aspect of the work's title. Readers of this collection of worthwhile essays will find that its focus is neither child language development nor bilingual education, but the general education of children through the monolingual medium of English in New Zealand public schools. The volume makes a significant contribution to the study of the successes and failures in recent and current efforts at the mainstreaming of minority language speakers in New Zealand schools, and to the analysis of the future needs of this educational project. Within this field, the essays in the volume examine a range of programs and experiences from a variety of perspectives. These include a survey of language issues in New Zealand (Roger Peddie's chapter 1); a survey of challenges facing nonEnglish-speaking students in primary schools (Penny Haworth's chapter 6); two studies of a literacy program involving Maori students and their parents (chapters 2 and 3 by Ted Glynn and Mere Berryman); a study of specific issues facing Samoan children (chapter 4 by John McCaffrey and Patisapa Tuafuti); case studies of a five-year-old Samoan and a twelve-year-old Korean learner (Elaine W. Vine's chapter 5 and Roger Barnard's chapter 7, respectively); a case study of deaf children in mainstream and bilingual contexts (Rachael Locker McKee and Yael Biederman's chapter 8); and two studies of bilingual students' educational needs, the first based on survey data from teachers (Nikhat Shameem's chapter 9) and the second on data from students (Donna Stuarks and Gary Barkhuizen's chapter 10). The issues raised and addressed in these articles are put in perspective by Roger Barnard's succinct introduction and Ted Glynn's summary of the work's themes and implications (chapter 11).

Among these themes, one of the most pervasive is the conspicuous absence of a New Zealand national language policy (see especially chapters 9 and 11). Fortunately for the linguistically-minded reader, however, the authors rarely stray over into purely political territory but retain their focus on what might contribute to effective educational policy for bilingual and bicultural students. In this regard, a pervasive concern of the authors is the need to move past the outmoded view of non-English-speaking background (NESB) students as deficient learners to 
one that sees them as empowered by their knowledge of a first language and culture (see especially chapters 5 and 6). Similarly, many of the authors promote approaches that see learning as a partnership or co-construction involving not only students and teachers - and parents - but schools and communities as well. In this regard, the two chapters by Glynn and Berryman (chapters 2 and 3 ) on a literacy program for Maori students are particularly instructive. The authors explain that the program began with the realization that parents were an undervalued and underused resource for local education. Given a modest amount of training and a good measure of cultural understanding, Maori parents with limited literacy became effective tutors. The authors ascribe much of the program's success to the manner in which it was adapted to the cultural practices and worldview of the Maori, leading to their conclusion that "schools need to adopt pedagogies that are congruent with the pedagogical practices of minority cultures" (p. 37).

Most of the contributors to the volume would agree with this claim. As Glynn puts it in his conclusion, "these chapters suggest a range of examples of culturally inclusive pedagogies that support the inclusion of students from different language and cultural backgrounds from their mainstream teachers and classmates" (p. 278). Glynn asserts that, by contrast, most second language instruction has amounted to "subtractive bilingualism," in which the students' first language and culture are submerged in order to substitute knowledge that "matters" in the new mainstream cultural context (p. 279). Similarly, McCaffery and Tuafuti argue that education for today's bilingual students must seek not only to counter the earlier marginalization of minority languacultures (a favorite term in this volume), but also to foster a "critical multiculturalism," which the authors define as the ability to "engage critically with all ethnic and cultural backgrounds" (p. 84). In other words, say these authors, the goal of today's multicultural education should not be the assimilation of minority students into mainstream society but the empowerment of these students though critical understanding achieved with their cultural distinctiveness and self-awareness intact.

As we move from the theoretical to the practical aspects of the research in this volume, however, the skies darken somewhat. Several of the contributions - notably chapter six from the standpoint of classroom observation, and chapters nine and ten from the standpoint of survey and interview data - provide the rudiments of an exploration of the development of teaching strategies tailored to the needs of NESB students. But whereas the authors of several of these chapters praise teachers for their application of intuition and experience in meeting these needs on an ad hoc basis, they paint a picture of mainstream teachers who are, broadly speaking, insufficiently trained to address NESB students' special educational needs. Moreover, they also point out that teachers are woefully under prepared in the area of cultural and (especially) linguistic knowledge of the minority communities they serve. Many of the authors see such knowledge as a vital ingredient in the successful teaching of NESB students in a mainstream context. Shameem, however, concludes that this is unlikely to happen unless the impetus comes from the minority communities themselves (p. 243).

Several studies in the collection shed doubt on the wisdom of the sink-or-swim practice of mainstreaming NESB students, even though these students receive pullout ESOL instruction (the authors point out that, as with many aspects of New Zealand education, this practice is pegged to United Kingdom norms). The first of these is one of the two tightly focused studies of individual learners in the volume: Barnard's study of private speech in a twelve-year-old Korean learner. 
As Barnard tells it, the tale of Jack's learning of English in a New Zealand classroom is hardly a success story. In fact, it leads the author to the general conclusion that "to place children in a conte $[\mathrm{x}] \mathrm{t}$ of incomprehensible input is to effectively deny them access to the curriculum" (p. 189). Curiously, the only study to specifically compare mainstream and bilingual education programs did not deal with students from any ethnic/cultural minority, but with two students whose first language was New Zealand Sign Language. Here, however, the finding was similar to Barnard's. McKee and Biederman find that the deaf students in a bilingual class at a specialized school benefited from the shared experience of having material taught in a way that was geared toward their sign-language mediated view of the world. By contrast, the single deaf student whose progress in a mainstream classroom the authors charted was clearly seen to give more than he took away from the experience. His classmates, say the authors, visibly benefited from first-hand experience of this student's diversity. The student himself, however, was merely forced to use his sign language skills in a perpetually unsatisfactory effort to learn according to mainstream norms.

Unlike some of the other contributors to this purportedly sociolinguistically oriented volume, McKee and Biederman do manage to pay meaningful attention to the socio-cultural context of interaction in which their research subjects are embedded. Their study, however, might be criticized for linking two observations carried out by different researchers at different times and under different parameters, rather than as part of a single study design. Similarly, although Barnard offers a useful account of the pragmatic functions of "private speech" (p. 171) and some general suggestions for strategies to cope with the pedagogical challenges presented by NESB students, his study raises some theoretical and methodological questions. It is unclear whether it is actually speech that Barnard is striving to investigate: "Once inner speech is consciously formulated, it loses its pristine quality and ceases to be pure thought" (p. 169; emphasis added). Also, one wonders if it is possible, as Barnard maintains, to equip a 12-yearold with a microphone and thereby record natural samples of his speech, private or otherwise. Not only is such a child fully conscious of the presence and purpose of such a device-leading to an observational effect that cannot be disentangled from the data-Jack's melodramatic performance in the transcribed passages suggests the likelihood that he is playing to the gallery.

On the whole, however, the essays in this volume are well-written, well thought out, and well chosen to contribute to the study of multilingual pedagogy in a part of the world that, after a few chapters, gradually starts to seem anything but remote. This is because with its mainstream English, indigenous Maori, and variety of community languages, New Zealand might actually be described as a microcosm of today's multicultural society. Perhaps, then, the authors of the next volume of this kind will not be afraid to put the words New Zealand on the cover.

\section{EUN-YOUNG KWON}

Teachers College, Columbia University 